\title{
Analysis of Learning Motivation on Students Activities of Package C Equality Program in Nganjuk District
}

\author{
Moh. Ghoizi Eriyanto, Maria Veronika Roesminingsih, \& Soedjarwo \\ Postgraduate Nonformal Education, State University of Surabaya, Surabaya, Indonesia \\ moh.ghoizi.19003@mhs.unesa.ac.id; roesminingsih@unesa.ac.id; soedjarwo@unesa.ac.id; \\ *Corresponding Author: moh.ghoizi.19003@mhs.unesa.ac.id
}

\begin{abstract}
McClelland's theory of motivation focuses on three needs, namely the need for achievement, the need for power, and the need for affiliation. This study method uses quantitative research with descriptive method. This study aims to determine whether learning motivation has an effect on student activity. Sources of research data were obtained from 3 PKBM institutions in Nganjuk Regency. The data were analyzed using descriptive analysis to determine the activity of the experimental and control classes. Active Observation (Psychomotor and Oral Activities) the average activity value reached $85.23 \%$. This percentage is included in the very good category. The t-test calculation of the activeness score shows tcount $>$ ttable. So it can be concluded that there is an influence of learning motivation on the activity of students in PKBM Nganjuk Regency.
\end{abstract}

Keywords: motivation; learn; activity; equality education;

\section{Introduction}

The Package $\mathrm{C}$ equivalence program as a non-formal educational institution has a very large role and responsibility in preparing reliable human resources and ready to face challenges in the future. Through these educational institutions a person will gain a variety of knowledge, experience and skills. Based on the definition above, it is known that the orientation of education is to mature and mature students, so that they will become personal figures who have independence in dealing with various problems, both those that arise during the educational process and those found in everyday life. Learning is the process of changing behavior to gain knowledge, abilities, and something new and directed at a goal. Learning is also a process of doing through various experiences by seeing, observing, and understanding something that is learned (Khanifatul, 2013).

The results of the preliminary pre-orientation research conducted at PKBM (Center for Community Learning Activities) and SKB (Study Activities Learning) Nganjuk Regency, researchers saw that students' learning motivation was still less than optimal as seen from 15 students who attended each activity no more than $50 \%$, when their learning is more outside the classroom. The learning motivation of students is different from one another, there are students who have quite high learning motivation and on the contrary there are students who have low learning motivation. This can be seen from the enthusiasm and attention of students in participating in learning. Based on the researcher's direct observation, the level of activeness of students is still low, it is proven when the learning process of students is passive, namely only listening to the explanation given by the tutor. Students' attention to learning is still lacking, which is marked by students who are still busy chatting with their classmates and engrossed in their own activities. In the subskills asking and answering questions, only a few students showed active opinion and asking questions. Questions made by students also did not show critical questions related to the material being studied. Then the answers to the questions are still limited to memory and understanding, there is no student attitude that shows an analytical answer to the tutor's questions. So it is also an indication that the learning motivation of the students of the Package C Equivalence Program in Nganjuk Regency is still not optimal.

In the world of psychology there is a theory of needs that motivates a person to do something. The theory was developed by David McClelland so it is often referred to as McClelland's theory of motivation. McClelland (in Satiadarma, 2000) proposes a theory of motivation based on the fulfillment of needs (need achievement theory) in which one of the components is individual personality. McCleland conveys a theory 
of motivation which is closely related to the concept of learning. The theory states that when a person has a strong need, the effect is to motivate someone to use behavior that leads to the fulfillment of the need for satisfaction. The essence of this theory is that needs are learned through adaptation to one's environment. Because the need is learned, the given behavior tends to occur at a higher frequency (Gibson, Ivancevich and Donnely, 2007: 111).

McClelland (in Walgito, 2010) suggests that social motives are complex motives and are the source of many human behaviors or actions. Social motives are important to get a picture of individual and group behavior. David McClelland (in Robbins, 2001) in his theory of McClelland's Achievement Motivation Theory or McClelland's theory of achievement motivation suggests that individuals have potential energy reserves, how this energy is released and developed depending on the strength or motivation of the individual and the available situations and opportunities. This theory focuses on three needs, namely the need for achievement, the need for power, and the need for affiliation. McClelland states the characteristics of individuals with high achievement motivation according to McClelland as follows: (1) The desire to be the best; (2) Likes work with personal responsibility; (3) Requires feedback after doing a job; (4) Moderate task selection risk; (5) Creative-innovative in doing a task or job.

\section{Literature Review}

According to McClelland, there are 2 types of need for power, namely personal and social. N-POW people are those who like to have power over everything, what they are after is power over everything. Measurable indicators: a) Instilling the influence of power on friends b) Does not have a high sense of empathy c) Wants to show his strengths d) Friends are a means to achieve goals e) Intolerant, too assertive, harmony is not the main thing.

The need for affiliation reflects the desire to interact socially with people. In another sense, the need for affiliation is the need to get good social relations in the work environment. A person with a high need for affiliation places the quality of personal relationships as the most important thing. Therefore, social relations take precedence over task completion. According to McClelland (in Rupawanti: Herfina Rinjani and Ari Firmanto, 2013: 79) people who have a high need for affiliation have the following aspects: a) Prefers to be with other people than alone; b) Often interacts with other people; c) Want to be liked and accepted by others; d) Pleasing others; e) Demonstrate and maintain a loyal attitude towards friends; $f$ ) Seek the approval and agreement of others.

The types of activity studied in this study were activities related to muscle work or psychomotor and oral activities. The indicators used for psychomotor are observing students in practicum activities: 1) Preparation of students before practicum; 2) Ability and skills in using tools and materials; 3) Accuracy in carrying out practical procedures; 4) Ability to cooperate in groups; 5) Accuracy in observing experimental results; 6) Accuracy in writing data; 7) Time discipline in completing the practicum; 8) Ability to clean and tidy up tools and practicum materials.

The indicators used for oral activities are: 1) Actively expressing ideas and ideas; 2) Activeness in asking questions; 3) Activeness in answering questions; 4) Active cooperation in group discussions; 5) Activeness in presenting the results of the discussion; 6) Activeness in refuting the statements of other group members; 7) Actively giving suggestions; 8) Activeness in conveying conclusions at the end of the lesson.

\section{Methods}

In this study, the researcher uses quantitative study with descriptive method. Quantitative study method is one type of research whose specifications are systematic, well-planned and clearly structured from the beginning to the making of the research design. The purpose of this study is to find out whether learning motivation affects student activity and the sources of research data are obtained from 3 Community Learning Activity Center institutions in the Nganjuk district, namely PKBM Harapan Jaya, PKBM Nurul Jadid, PKBM Nurul Jamal.

In terms of the implementation process, the data collection technique used was non-participant observation, while based on the instrumentation, the technique used was structured observation guided by the observation instrument to make direct observations of the learning implementation process. At the time of observation, the researcher filled out the available observation instruments by providing a check list in the available column. This observation was carried out by two observers, namely the researcher himself and one of the tutors.

Testing for normality in this study using Kolmogorov-Smirnov using Microsoft Excel, starting with the data sorted from smallest to largest, determining the mean $(\bar{x})$ and standard deviation (s), determining the $\mathrm{z}$ table, determining $f(z)$, and the last one specifies $[s(z)-f(z)]$. To find the average using the formula "=AVERAGE (number 1, 2...", standard deviation using the formula "=STDEV (number $1,2 \ldots$ ), z using the 
formula " $\mathrm{z}=(\mathrm{x}-\overline{\mathrm{x}}) / \mathrm{s}$ ", $\mathrm{f}(\mathrm{z})$ using the formula "=NORMSDIST $(\mathrm{z})$ ", for everything without using quotes.

The test criteria, if $[\mathrm{s}(\mathrm{z})-\mathrm{f}(\mathrm{z})]$ count $[\mathrm{s}(\mathrm{z})-\mathrm{f}(\mathrm{z})]$ table then the sample comes from a normally distributed population, and if $[\mathrm{s}(\mathrm{z})-\mathrm{f}(\mathrm{z})]$ count $>[\mathrm{s}(\mathrm{z})-\mathrm{f}(\mathrm{z})]$ table then the sample comes from an abnormal population, (Awaluddin, 2014:72). The analysis used is descriptive analysis which aims to determine the value of student activity in both the experimental class and the control class. The formula used is: $=100 \%$.

From the activity assessment, it can be categorized as very good if the score is $80 \%$, good category if the score is $60 \%-79 \%$, sufficient category if the score is $40 \%-59 \%$, bad category if the score is $30 \%-39 \%$, and very bad category if the score $<29 \%$. Each aspect of activity can be categorized as very good if the average value is $3.4-4.0$; good category if the average value is $2.8-3.3$; medium category if the average value is $2.2-$ 2.7; low category if the average value is $1.6-2.1$; and very low category if the average value is 1.0-1.6. The data analysis technique in the questionnaire is descriptive in the form of an explanation of the percentage of each aspect of achievement motivation, affiliation motivation, and strength motivation as well as quantitative analysis with inferential statistical techniques using t-test statistics. The $\mathrm{t}$-test criteria can be said to be significant if the $p<0.05$ is obtained and the hypothesis testing accepts Ho if tcount $<t$ table (1-a) and accepts Ha if $t_{\text {count }}>t$ table $(1-\alpha)$. The statistical calculations were carried out using the SPSS For Window Series 23.0 program.

\section{Results and Discussions}

\subsection{Results}

The normality test was conducted to determine whether the subjects used were subjects with normal distribution or not. In this study, the normality test used was the Kolmogorov-Smirnov test. The results of the normality test for the experimental class and the control class can be seen in the table 1 .

Table 1. Normality Test Results

\begin{tabular}{ccccc}
\hline \multirow{2}{*}{ Statistics } & \multicolumn{2}{c}{ Experiment Class } & \multicolumn{2}{c}{ Control Class } \\
\cline { 2 - 5 } & Pretest & Posttest & Pretest & Posttest \\
\hline$N$ & 96 & 96 & 96 & 20,906 \\
\hline Mean $(\bar{x})$ & 5,635 & 23,708 & 57,440 & 3,506 \\
\hline Standard Deviation & 1,086 & 3,185 & 1,122 & 0,072 \\
\hline L Count & 0,083 & 0,08 & 0,08 & 0,090 \\
\hline L table & 0,090 & 0,090 & 0,090 & Normal distribution \\
\hline Conclusion & Normal distribution & Normal distribution & Normal distribution & Nor
\end{tabular}

Based on the table above, the normality test criteria is that the value of $\mathrm{L}_{\text {count }}<\mathrm{L}_{\text {table, }}$ then the data is normally distributed, while if the value of $\mathrm{L}_{\text {count }}>\mathrm{L}_{\text {table }}$ then the data is not normally distributed. It can be seen from the pretest table above in the experimental class that the $\mathrm{L}_{\text {count }}$ value is $0.083<\mathrm{L}_{\text {table }}$ is 0.090 , then the experimental class pretest value data is normally distributed. In this study, the homogeneity test used the $\mathrm{F}$ test. For a significant level $=0.05$. The results of the homogeneity test are in the table 2 .

Tabel 2. Homogeneity Test Results

\begin{tabular}{ccccc}
\hline \multirow{2}{*}{ Statistics } & \multicolumn{2}{c}{ Pretest } & \multicolumn{2}{c}{ Posttest } \\
\cline { 2 - 4 } & Experiment Class & Control Class & Experiment Class & Control Class \\
\hline Varians & 1,181 & 1,260 & 10,145 & 12,296 \\
\hline F Count & 0,937 & 1,59 \\
\hline F table & \multicolumn{2}{c}{1,59} & Homogeneous \\
\hline Conclusion & \multicolumn{2}{c}{ Homogeneous }
\end{tabular}

Based on the results of the homogeneity calculation, it was found that the two samples were homogeneous. So the results from Tables 1 and 2 support the results of the researcher's interview with the Curriculum Waka which stated that the grouping of groups when students entered the three schools was not based on achievement so that the ability between classes was the same. 
Table 3. Average Value of Each Aspect of PKBM Experimental Class Activity in Nganjuk Regency

\begin{tabular}{clcc}
\hline \multicolumn{1}{c}{ Aspecs } & Average value & Criteria \\
\hline No & & 3,41 & Very Good \\
\hline 1 & Preparation of students before practicum & 3,47 & Very Good \\
\hline 3 & Ability and skill in using tools and materials & 3,16 & Good \\
\hline 4 & Accuracy in carrying out practical procedures & 3,06 & Good \\
\hline 5 & Acculity to cooperate in groups in observing experimental results & 4 & Very Good \\
\hline 6 & Accuracy in data writing & 4 & Very Good \\
\hline 7 & Time discipline in completing practicum & 4 & Very Good \\
\hline 8 & The ability of students to clean and tidy up the tools and practicum materials & 3 & Good \\
\hline 9 & Actively express ideas and ideas & 2,81 & Good \\
\hline 10 & Activeness in asking questions & 3,56 & Very Good \\
\hline 11 & Activeness in answering questions & 3,22 & Good \\
\hline 12 & Active collaboration in group discussions & 3,03 & Good \\
\hline 13 & Activeness in presenting the results of the discussion & 3,16 & Good \\
\hline 14 & Activeness in refuting the statements of other groups & 3,94 & Very Good \\
\hline 15 & Ability to give advice & 3,81 & Very Good \\
\hline 16 & Activeness in conveying conclusions at the end of the lesson & 3,69 & Very Good \\
\hline
\end{tabular}

Based on the data above, it can be concluded that in psychomotor activity there are five aspects of achieving very good criteria and three aspects of achieving good criteria. The four aspects of oral activities achieved the very good criteria and four aspects reached the good criteria. The average value of the activeness of the PKBM experimental class in Nganjuk Regency reached $85.23 \%$. The percentage score is included in the very good category.

Table 4. Average Value of Each Aspect of Control Class PKBM Nganjuk Regency

\begin{tabular}{|c|c|c|c|}
\hline No. & Aspecs & Average value & Criteria \\
\hline 1 & Preparation of students before practicum & 3,1 & Good \\
\hline 2 & Ability and skill in using tools and materials & 2,54 & Medium \\
\hline 3 & Accuracy in carrying out practical procedures & 2,98 & Good \\
\hline 4 & Ability to cooperate in groups & 3,21 & Good \\
\hline 5 & Accuracy in observing experimental results & 3,89 & Very Good \\
\hline 6 & Accuracy in data writing & 3,73 & Very Good \\
\hline 7 & Time discipline in completing practicum & 3,55 & Very Good \\
\hline 8 & The ability of students to clean and tidy up the tools and practicum materials & 2,75 & Medium \\
\hline 9 & Actively express ideas and ideas & 2,83 & Good \\
\hline 10 & Activeness in asking questions & 3,25 & Good \\
\hline 11 & Activeness in answering questions & 2,24 & Medium \\
\hline 12 & Active collaboration in group discussions & 2,5 & Medium \\
\hline 13 & Activeness in presenting the results of the discussion & 2,79 & Medium \\
\hline 14 & Activeness in refuting the statements of other groups & 3,05 & Good \\
\hline 15 & Ability to give advice & 2,79 & Medium \\
\hline 16 & Activeness in conveying conclusions at the end of the lesson & 3,64 & Very Good \\
\hline
\end{tabular}

Based on the data above, it can be concluded that in psychomotor activity there are three aspects of achieving excellent criteria, three aspects of achieving good criteria, and two aspects of achieving moderate criteria. In the oral activities, one aspect reached the very good criteria, three aspects reached the good criteria, and four aspects reached the moderate criteria. The average value of the PKBM control class activity in Nganjuk Regency reached $76.31 \%$. The percentage score is included in the good category. From the results above, the average activeness value of the experimental class is better than the control class. So that it can be said that there is a difference in student activity between the provision of learning motivation and those who are not given Package C motivation at PKBM, Nganjuk Regency, the activity is increased when students are given motivation to learn.

\section{Conclusion}

Based on the calculation of the t-test, the activity score shows $t_{\text {count }}>t_{\text {table. }}$. So it can be concluded that there is an influence of learning motivation on the activity of students in PKBM Nganjuk Regency. 


\section{Acknowledgement}

The authors would like to thanks to the people who have been instrumental in their assistance and the successful completion of this study.

\section{Author's Contribution}

All authors discussed the result and contributed to from the start to final manuscript.

\section{Conflict of Interest}

The authors declare that they have no competing interests.

\section{References}

Ahmadi, A \& Widodo, S. (2004). Psikologi Belajar. Jakarta: Rineka Cipta.

Johnson, E. (2011). CTL: Contextual Teaching \& Learning. Bandung: Kaifa.

Khanifatul. (2013). Pembelajaran Inovatif: Strategi Mengelola Kelas Secara efektif dan Menyenangkan. Jogjakarta: ArRuzz Media.

Mcclellan, C. D. (1976). The Achievemen Motive. New York: Irvington Publisher.

McGregor, D. (2007). Developing Thinking Developing Learning. New York: Open University Press.

Moslow H. A. (1970). Motivation And Personality. New York: Harpen And Row Publisher.

Sudjana, N (2009). Penilaian Hasil Proses Belajar Mengajar. Bandung: PT Remaja Rosdakarya.

Sanjaya, W. (2009). Strategi Pembelajaran Berorientasi Standar Proses Pendidikan. Jakarta: Kencana.

Santrock, J. W. (2011). Psikologi Pendidikan, Edisi Kedua. Jakarta: Kencana.

Sardiman. (2012). Interaksi dan Motivasi Belajar Mengajar. Jakarta: PT Raja Grafindo Persada.

Sihotang, K. (2012). Critical Thinking. Jakarta: Pustaka Sinar Harapan.

Sudjana. (2002). Metoda Statistika. Bandung: Tarsito.

Sugiyono. (2010). Metode Penelitian Pendidikan. Bandung: Alfabeta

Sugiyono. (2011). Statistik Untuk Penelitian, cet XII. Bandung: Alfabeta

Suprijono, Agus. (2010). Cooperative Learning. Yogyakarta. Pustaka Media.

Suryabrata, Sumadi. (1984). Psikologi Pendidikan. Jakarta: Rajawali.

UNESA. (2000). Pedoman Penulisan Artikel Jurnal, Surabaya: Lembaga Penelitian Universitas Negeri Surabaya.

Warsono \& Hariyanto. (2012). Pembelajaran Aktif. Bandung: PT Rosdakarya.

Zaitun, B. (1979). Manajemen Dan Motivasi. Jakarta: Balai Aksara. 